\title{
PENGARUH TINGKAT LIKUIDITAS DAN RENTABILITAS TERHADAP KECUKUPAN MODAL
}

(Studi pada Bank Panin Syariah)

\author{
Agus Mustopo \\ Mardiansyah \\ STAI PELITA BANGSA \\ agus.mustopo@pelitabangsa.ac.id
}

\begin{abstract}
ABSTRAK
Penelitian ini bertujuan untuk menganalisis seberapa besar pengaruh likuiditas yang diukur dengan Financing to Deposit Ratio (FDR) dan rentabilitas yang diukur dengan Return On Asset (ROA) terhadap kecukupan modal yang diukur dengan Capital Adequacy Ratio (CAR) pada PT. Bank Panin Syariah Tbk. Data yang digunakan dalam penelitian ini adalah data sekunder yaitu laporan keuangan triwulan PT. Bank Panin Syariah Tbk. periode 2011 - 2015. Teknik analisis data yang digunakan adalah regresi linier berganda, lengkap dengan uji asumsi klasik (normalitas, multikolinieritas, heteroskedasitas, dan autokorelasi). Hipotesis diuji menggunakan uji t dan uji $\mathrm{F}$ dengan tingkat signifikansi 5\%. Berdasarkan hasil uji parsial menggunakan uji t, diketahui bahwa tingkat likuiditas berpengaruh signifikan positif terhadap kecukupan modal. Sedangkan, tingkat rentabilitas berpengaruh signifikan negatif terhadap kecukupan modal. Secara simultan, likuiditas dan rentabilitas berpengaruh signifikan terhadap kecukupan modal, yaitu sebesar $54.1 \%$, sedangkan sisanya $45.9 \%$ dipengaruhi oleh faktor-faktor lain di luar penelitian.
\end{abstract}

Kata Kunci : Likuiditas (FDR), Rentabilitas (ROA), dan Kecukupan Modal (CAR)

ABSTRACT

This research aims to analyze how big the influence of liquidity as measured by Financing to Deposit Ratio (FDR) and rentability as measured by Return On Asset (ROA) to capital adequacy as measured by Capital Adequacy Ratio (CAR) at PT. Bank Panin Syariah Tbk. The research uses secondary data that was taken from quarterly financial report of PT. Bank Panin Syariah Tbk. period $2011-$ 2015. Data analysis is done by multiple linear regression as a statistic tool, complete with the classic assumption test (normality, multicolinearity, heteroscedasticity, and autocorrelation). The hypotheses is tested using t-test and $F$-test with a significance level of 5\%. Based on the results of partial test using $t$ test, it's known that the level of liquidity has a significant positive effect on capital adequacy. Meanwhile, the level of rentability has a significant negative effect on capital adequacy. Simultaneously, liquidity and rentability have significant effect to capital adequacy that amounted to $54.1 \%$, while the remaining $45.9 \%$ are influenced by other factors outside the research.

Keyword : Liquidity (FDR), Rentability (ROA), dan Capital Adequacy Ratio $(C A R)$ 


\section{PENDAHULUAN}

Perbankan merupakan pilar terpenting dalam membangun sistem perekonomian dan keuangan suatu negara. Karena perbankan memiliki peranan yang sangat penting sebagai intermediary institution yaitu lembaga keuangan yang menghubungkan dana-dana yang dimiliki oleh unit ekonomi yang memiliki dana lebih (surplus) kepada unit-unit ekonomi yang membutuhkan dana (deficit).

Di Indonesia, terdapat 2 sistem perbankan, salah satunya adalah Perbankan Islam. Perbankan Islam adalah suatu sistem perbankan nasional yang pelaksanaannya berdasarkan prinsip Islam (syariah), demokrasi ekonomi, dan prinsip kehatihatian. Yang dimaksud berdasarkan prinsip Islam adalah kegiatan usaha yang tidak mengandung unsur riba, maisir, dan gharar, serta objek usaha yang dijalankan tidak tergolong dalam kategori terlarang (haram). Sedangkan, yang dimaksud berdasarkan prinsip demokrasi adalah kegiatan usaha yang menerapkan nilai-nilai keadilan, kejujuran, dan kebersamaan.

Bisnis perbankan merupakan bisnis jasa yang saat ini berada dalam persaingan yang ketat, tidak terkecuali perbankan syariah. Oleh karena itu, untuk unggul dan bertahan dalam persaingan maka bank harus memelihara kepercayaan masyarakat dengan cara senantiasa menjaga kinerja kesehatannya.

Dalam hal ini, Bank Indonesia menilai tingkat kesehatan bank berdasarkan pendekatan kualitatif atas berbagai aspek yang berpengaruh terhadap kondisi suatu bank. Metode atau cara penilaian tingkat kesehatan bank tersebut kemudian dikenal dengan metode Risk Based Bank Rating (RBBR) yang menggantikan CAMELS, tertuang pada Peraturan Bank Indonesia nomor 6/10/PBI/2004. Pelaksanaan RBBR didasarkan pada 4 faktor, yaitu Profit Risiko, Good Corporate Governance (GCG), Rentabilitas, dan Permodalan. Beberapa rasio keuangan yang akan penulis bahas dalam penelitian ini adalah:

1. Rasio Likuiditas yang diukur dengan FDR (Financing to Deposit Ratio). FDR adalah rasio perbandingan antara seluruh jumlah kredit yang diberikan bank dengan dana masyarakat yang dikumpulkan bank. Tingkat kesehatannya maksimal $110 \%$.

2. Rasio Rentabilitas atau Profitabilitas yang diukur dengan ROA (Return On Asset). ROA dipilih sebagai indikator pengukur kinerja keuntungan bank, karena digunakan untuk mengukur kemampuan perusahaan di dalam menghasilkan keuntungan dengan memanfaatkan aktivanya. Tingkat kesehatannya berkisar antara $0.5 \%$ s.d. $1.25 \%$.

3. Rasio Kecukupan Modal yang diukur dengan CAR (Capital Adequacy Ratio). CAR adalah rasio kemampuan bank untuk mengukur kemampuan dalam mempertahankan kecukupan modal yang dimiliki bank untuk menunjang aktiva yang mengandung risiko. Tingkat kesehatannya minimal $8 \%$.

Di samping bisnis perbankan, faktor permodalan adalah hal yang sangat menentukan besarnya keuntungan bank, karena pada hakikatnya modal inilah yang ditanam oleh bank untuk mendapatkan keuntungan. Jumlah modal berbanding lurus dengan jumlah keuntungan, artinya semakin banyak modal yang disetorkan maka semakin besar pula keuntungan yang didapatkan. Modal juga harus dapat dikelola untuk menjaga kemungkinan terjadinya risiko kerugian atas investasi aktiva, terutama yang berasal dari dana-dana pihak ketiga. 
Peningkatan peran aktiva sebagai pengasil keuntungan secara simultan bersamaan dengan pertimbangan risiko yang mungkin timbul, guna melindungi kepentingan para pemilik dana. Upaya memenuhi tingkat kecukupan modal, sebagaimana yang telah diatur oleh Bank Indonesia merupakan hal yang sangat penting untuk diperhatikan karena tingkat kecukupan modal mencerminkan kemampuan bank dalam menanggung risiko kerugian yang mungkin timbul.

Sementara itu, tingkat likuiditas berbanding terbalik dengan tingkat rentabilitas. Apabila tingkat likuiditas bank tinggi, maka tingkat rentabilitasnya rendah, begitu juga sebaliknya. Pengelolaan likuiditas dan rentabilitas dapat berpengaruh terhadap perkembangan dan kelangsungan bank tersebut. Kegagalan dalam mengelola likuiditas dan rentabilitas memiliki konsekuensi yang mengerikan, mulai dari ketidakstabilan sistem keuangan hingga kolapsnya bank tersebut.

Perusahaan perbankan merupakan suatu jenis perusahaan yang erat kaitannya dengan risiko karena melibatkan pengelolaan uang milik masyarakat dan dikelola kembali dalam berbagai bentuk pembiayaan, sehingga menyebabkan fluktuasi laporan keuangan yang cukup signifikan, terutama pada fluktuasi laba.

Salah satu media online, tempo.co tahun 2015 memuat berita mengenai pernyataan Direktur Perbankan Syariah Otoritas Jasa Keuangan (OJK), Dhani Gunawan Idhat yang mengatakan bahwa terdapat beberapa permasalahan yang menjadi tantangan dan perlu diatasi oleh perbankan syariah agar dapat maju dan berkembang. Salah satunya adalah permasalahan modal perbankan syariah yang tentunya berkaitan erat dengan tingkat likuiditas dan rentabilitas bank syariah tersebut. Menurut beliau, dari total 12 bank syariah saat ini, 6 bank masih berada dikategori BUKU 1 atau permodalan kurang dari Rp 1.000.000.000.000,-, dan 6 bank lainnya berada pada kategori BUKU 2 atau permodalan antara Rp 1.000.000.000.000,- s.d. Rp 5.000.000.000.000,-.

Penelitian yang dilakukan oleh Rizka Kyky Damayanti, Sujarwo, dan Taufikul Ichsan (2016), ROA berpengaruh signifikan positif terhadap CAR, sedangkan FDR berpengaruh signifikan negatif terhadap CAR. Begitu juga dengan penelitian yang dilakukan oleh Cynthia Edginarga (2012) dan Fahmi Fachrudin Syah (2013), ROA berpengaruh signifikan positif terhadap CAR, sedangkan FDR tidak berpengaruh signifikan terhadap CAR. Kemudian, terdapat hasil yang berbeda dalam penelitian yang dilakukan oleh Mochamad Rizal Maolany dan Helliana Nurhayati (2015), di mana FDR berpengaruh signifikan positif terhadap CAR, sedangkan ROA berpengaruh signifikan negatif terhadap CAR. Sedangkan, penelitian lain yang dilakukan Siti Fatimah (2013), ROA berpengaruh signifikan negatif terhadap CAR, sedangkan FDR berpengaruh signifikan negatif terhadap CAR.

1. Apakah likuiditas (FDR) berpengaruh terhadap kecukupan modal (CAR) pada PT. Bank Panin Syariah Tbk.?

2. Apakah rentabilitas (ROA) berpengaruh terhadap kecukupan modal (CAR) pada PT. Bank Panin Syariah Tbk.?

3. Apakah likuiditas (FDR) dan rentabilitas (ROA) berpengaruh terhadap kecukupan modal (CAR) pada PT. Bank Panin Syariah Tbk.?

Penelitian Terdahulu

\begin{tabular}{|l|l|l|l|}
\hline No & Nama Peneliti & Variabel Penelitian & Hasil \\
\hline 1. & Rizka Kyky & Rentabilitas, \\
& $\begin{array}{l}\text { Damayanti, } \\
\text { Sujarwo, dan } \quad \text { daniditas, Kecukupan } \\
\text { modal }\end{array}$ & $\begin{array}{l}\text { ROA secara parsial berpengaruh signifikan positif } \\
\text { terhadap CAR. FDR secara parsial berpengaruh } \\
\text { signifikan negatif terhadap CAR. }\end{array}$ \\
\hline
\end{tabular}




\begin{tabular}{|c|c|c|c|}
\hline & Taufikul Ichsan & & $\begin{array}{l}\text { ROA dan FDR secara simultan berpengaruh } \\
\text { signifikan terhadap CAR. }\end{array}$ \\
\hline 2. & $\begin{array}{l}\text { Cynthyia } \\
\text { Edginada }\end{array}$ & $\begin{array}{l}\text { Rasio Rentabilitas, } \\
\text { Likuiditas, Capital } \\
\text { Adequacy Ratio }\end{array}$ & $\begin{array}{l}\text { ROA secara parsial berpengaruh signifikan terhadap } \\
\text { CAR dengan nilai probabilitas }<0.05 \text {. LDR secara } \\
\text { parsial tidak berpengaruh signifikan terhadap CAR. } \\
\text { Secara simultan, ROA dan LDR terbukti } \\
\text { berpengaruh signifikan terhadap CAR dengan nilai } \\
\text { probabilitas }<0.05 \text {. }\end{array}$ \\
\hline 3. & Siti Fatimah & $\begin{array}{l}\text { Rentabilitas, Efisiensi, } \\
\text { Likuiditas, kecukupan } \\
\text { modal }\end{array}$ & $\begin{array}{l}\text { Jenis data yang adalah kuantitatif. } \\
\text { Data yang digunakan adalah laporan keuangan Bank } \\
\text { Syariah Mandiri periode Januari } 2009 \text { s.d. Desember } \\
2012 \text {. } \\
\text { Metode statistik menggunakan metode analisis } \\
\text { VECM (Vector Error Correction Model). } \\
\text { ROA secara parsial berpengaruh signifikan negatif } \\
\text { terhadap CAR. } \\
\text { FDR secara parsial berpengaruh signifikan negatif } \\
\text { terhadap CAR. } \\
\text { ROA dan FDR secara simultan berpengaruh } \\
\text { signifikan terhadap CAR. }\end{array}$ \\
\hline 4. & $\begin{array}{l}\text { Mochamad Rizal } \\
\text { Maolany, Helliana } \\
\text { Nurhayati }\end{array}$ & $\begin{array}{l}\text { Likuiditas, } \\
\text { Pofitabilitas, } \\
\text { Kecukupan Modal }\end{array}$ & $\begin{array}{l}\text { Pengaruh Likuiditas (FDR) dan Profitabilitas (ROA) } \\
\text { Terhadap Kecukupan Modal (CAR) Pada PT. Bank } \\
\text { Syariah Mandiri Periode } 2008-2013\end{array}$ \\
\hline
\end{tabular}

\section{PERBANKAN SYARIAH, LIKUIDITAS, RENTABILITAS, DAN KECUKUPAN MODAL}

Bank syariah adalah lembaga keuangan yang usaha pokoknya memberi pembiayaan dan jasa-jasa lain dalam lalu lintas pembayaran serta peredaran uang yang beroperasi disesuaikan dengan prinsip-prinsip syari'ah (Sudarsono, 2004).

Bank umum syariah yang pertama di Indonesia, lahir Mei 1992 dengan otoritas modal 500 miliar (kira-kira 250 juta US dollar menurut kurs tahun 1992) dan membayar penuh modal 135 miliar atau 67,5 juta US dollar dan menjadi bank baru dengan jumlah pembayaran modal yang besar yang pernah ada. Dengan lebih dari 100 ribu pemegang saham, bergerak dari bank kecil pemerintah hingga kalangan pebisnis dan konglomerat, Bank Muamalat Indonesia dianggap sebagai "bank rakyat".

Diawal-awal beroperasinya, rekening giro Bank Muamalat Indonesia berdasarkan prinsip wadi'ah dan penyimpanan serta rekening investasi berdasarkan prinsip mudharabah. Berkenaan dengan pembiayaan, bank mengembangkan produk pembiayaan pembelian investasi barang dan modal kerja masing-masing berdasarkan prinsip pada bai' bithaman ajil dan murabahah (Hakim, 2011).

Bank syariah, seperti halnya bank konvensional, pun harus memperhatikan hal-hal sebagai berikut:

a. Likuiditas, yaitu kemampuan bank untuk melunasi kewajiban sewaktu-waktu atau saat jatuh tempo atau dapat melunasinya dalam jangka pendek.

b. Solvabilitas, yaitu kemampuan bank untuk memenuhi seluruh kewajibannya bila bank tersebut tutup, atau dapat melunasinya dalam jangka pendek maupun jangka panjang.

c. Rentabilitas, yaitu kemampuan bank untuk memperoleh keuntungan atau laba agar dapat terjaga kontinuitasnya.

d. Soliditas, yaitu kemampuan bank untuk memperoleh kepercayaan dari masyarakat, sehingga menunjukkan bahwa bank dalam kondisi sehat.

Likuiditas adalah kemampuan manajemen bank dalam menyediakan dana yang cukup untuk memenuhi kewajibannya setiap saat. Dalam kewajiban di atas, 
termasuk penarikan yang tidak dapat diduga seperti commitment loan maupun penarikan-penarikan tidak terduga lainnya.

Likuiditas bisnis perbankan adalah kemampuan sebuah bank untuk menyediakan alat-alat lancar guna membayar kembali titipan yang jatuh tempo dan memberikan pinjaman kepada nasabah yang membutuhkannya.

Karena likuiditas perbankan adalah kemampuan bank untuk memenuhi kewajibannya, terutama kewajiban jangka pendek maka likuiditas mempunyai peranan penting dalam keberhasilan pengelolaan bank, sebab likuiditas diperlukan, antara lain untuk:

1. Pemenuhan dana reserve requirement atau cadangan wajib minimum yang ditetapkan bank sentral;

2. Penarikan dana oleh deposan;

3. Penarikan dana oleh debitur;

4. Pembayaran kewajiban yang jatuh tempo.

Pentingnya likuiditas dapat dilihat dengan mempertimbangkan dampak yang berasal dari ketidakmampuan bank memenuhi kewajiban jangka pendeknya. Kurangnya likuiditas menghalangi perusahaan untuk memperoleh keuntungan, juga berarti pembatasan kesempatan dan tindakan manajemen.

Masalah likuiditas yang parah dapat mencerminkan ketidakmampuan perusahaan untuk memenuhi kewajiban lancar dan dapat mengarah pada penjualan investasi dan aktiva dengan terpaksa, dan dalam bentuk yang lebih parah, mengarah pada insolvensi dan kebangkrutan.

Likuiditas bank biasanya disebut alat likuid atau reserve requirement atau simpanan uang di Bank Indonesia dalam bentuk Giro dalam jumlah yang ditentukan, disebut Giro Wajib Minimum. Dengan demikian, suatu bank syariah dikatakan likuid apabila:

Dapat memelihara Giro Wajib Minimum di Bank Indonesia sesuai dengan ketentuan yang berlaku.

Dapat memelihara giro di bank koresponden. Giro di bank koresponden adalah rekening yang dipelihara di bank koresponden yang besarnya ditetapkan berdasarkan saldo minimum.

Dapat memelihara sejumlah kas secukupnya untuk memenuhi pengambilan uang tunai.

Financing to Deposit Ratio (FDR)

Financing to Deposit Ratio (FDR) atau yang dalam bank konvensional disebut juga Loan to Deposit Ratio (LDR) merupakan rasio untuk mengukur kemampuan bank dalam memenuhi kewajibannya yang berasal dari permintaan pembiayaan. Rasio ini dihitung dengan membandingkan komposisi jumlah pembiayaan yang diberikan dengan jumlah dana pihak ketiga.

Loan to Deposit Ratio ini menyatakan kemampuan bank dalam membayar kembali penarikan dana yang dilakukan deposan dengan mengendalikan kredit yang diberikan sebagai sumber likuiditasnya, atau dengan kata lain, seberapa jauh pemberian kredit kepada nasabah dapat mengimbangi kewajiban bank untuk segera memenuhi permintaan deposan yang hendak menarik kembali dananya yang telah disalurkan oleh bank berupa kredit.

Pada penelitian bank syariah digunakan rasio pembiayaan terhadap dana pihak ketiga disebut FDR (Financing to Deposit Ratio) yaitu perbandingan antara kredit 
yang disalurkan dengan dana masyarakat yang dikumpulkan bank baik berupa tabungan, giro, maupun deposito. FDR memberikan indikasi mengenai jumlah dana pihak ketiga yang disalurkan dalam bentuk pembiayaan. Besarnya Financing to Deposit Ratio menurut peraturan pemerintah maksimum adalah $110 \%$.

Dengan ditetapkannya batas maksimum pemberian kredit (pembiayaan) dan Financing to Deposit Ratio yang harus diperhatikan oleh bank syariah, maka bank syariah tidak dapat secara berlebihan melakukan ekspansi pembiayaan dengan tujuan memperoleh keuntungan yang sebesar-besarnya, karena hal ini akan membahayakan kelangsungan hidup bank tersebut dan lebih lanjut akan membahayakan dan simpanan para nasabah penyimpan dari bank itu. Rumus yang digunakan untuk menghitung FDR yaitu:

$$
\mathrm{FDR}=\frac{\text { Total Pembiayaan yang Diberikan }}{\text { Total Dana Pihak Ketiga dan Ekuitas }} \times 100 \%
$$

Kemampuan perusahaan untuk menghasilkan laba akan dapat menarik para investor untuk menanamkan dananya guna memperluas usahanya, sebaliknya tingkat profitabilitas yang rendah akan menyebabkan para investor menarik dananya. Sedangkan bagi perusahaan itu sendiri, profitabilitas dapat digunakan sebagai evaluasi atau efektivitas pengelolaan badan usaha tersebut. Dengan demikian, bagi investor jangka panjang akan sangat berkepentingan dengan analisa profitabilitas ini (Djawanto, 1997).

Profitabilitas atau Rentabilitas adalah kemampuan bank untuk memperoleh keuntungan. Hal ini terlihat pada perhitungan tingkat produktivitasnya, yang ditunjukkan dalam Return On Asset (ROA). Jika kredit tidak lancar, maka profitabilitasnya menjadi kecil. Return On Asset (ROA) memiliki dua elemen, yaitu elemen yang dapat dikontrol dan elemen yang tidak dapat dikontrol. Rentabilitas bisnis perbankan (banking business profitability) adalah kesanggupan bisnis perbankan untuk memperoleh laba berdasarkan investasi yang dilakukannya (Sastradipoera).

Modal Sendiri Bank adalah sejumlah uang tunai yang telah disetorkan pemilik dan sumber-sumber lainnya yang berasal dari dalam bank itu sendiri.

Fungsi utama dari modal bank adalah melindungi para penyimpan uang (deposan) dari kerugian yang timbul. Walaupun pernyataan di atas mengandung kebenaran tetapi tidak cukup mengungkapkan sikap-sikap asli dari fungsi protektif dari modal bank. Modal bank adalah manifestasi dari keinginan para pemegang saham untuk berperan dalam bisnis perbankan. Modal bank digunakan untuk menjaga kepercayaan masyarakat, khususnya masyarakat peminjam. Kepercayaan masyarakat akan terlihat dari besarnya dana giro, deposito dan tabungan yang harus melebihi jumlah setoran modal dari pemegang saham.

Agar perbankan dapat berkembang secara sehat dan mampu bersaing dalam perbankan internasional, maka permodalan bank harus senantiasa mengikuti aturan yang berlaku secara internasional, yang ditentukan oleh Banking International Settlement (BIS), yaitu Capital Adequacy Ratio (CAR) sebesar 8\%.

Besarnya CAR diukur dari rasio antara modal bank terhadap Aktiva Tertimbang Menurut Risiko (ATMR). Menurut PBI No. 10/15/PBI/2008 Pasal 2, Bank wajib menyediakan modal minimum sebesar $8 \%$ (delapan persen) dari Aset Tertimbang Menurut Risiko (ATMR).

Rumus yang digunakan untuk menghitung CAR yaitu: 


$$
\mathrm{CAR}=\frac{\text { Modal Bank }}{\text { Aktiva Tertimbang Menurut Risiko (AMTR) }} \times 100 \%
$$

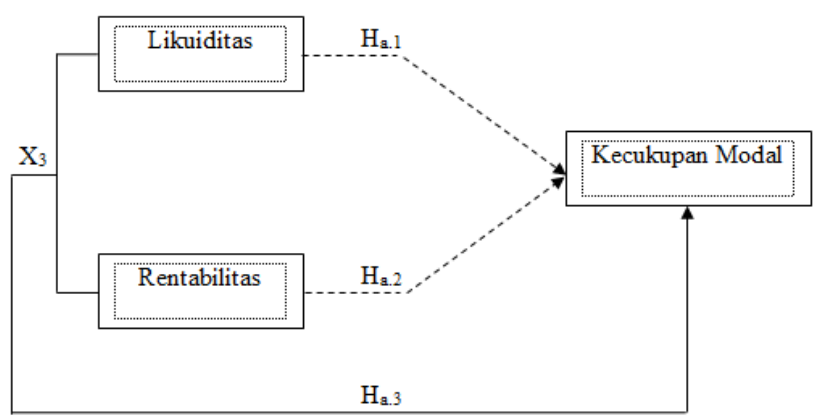

Hipotesis penelitian ini adalah sebagai berikut:

Ha.1 : Likuiditas berpengaruh signifikan positif terhadap kecukupan modal Ha.2 : Rentabilitas berpengaruh signifikan positif terhadap kecukupan modal Ha.3 : Likuiditas dan Rentabilitas berpengaruh signifikan positif terhadap kecukupan modal

\section{METODE PENELITIAN}

Jenis penelitian yang digunakan adalah penelitian deskriptif dengan pendekatan kuantitatif. Variabel yang digunakan adalah variabel bebas (independen) meliputi likuiditas (FDR) dan rentabilitas (ROA), serta variabel terikat (dependen) meliputi tingkat kecukupan modal (CAR).

Pendekatan kuantitatif digunakan dalam melakukan pengumpulan dan penginventarisasian data yang berhubungan dengan angka, rumus, dan rasio yang diperoleh dari data laporan keuangan triwulan di Bank Panin Syariah Tbk. selama periode 2011-2015, yang kemudian akan diolah dan dianalisis secara sistematis dan akurat untuk menguji kebenaran hipotesis, sampai pada penyajian hasil disertai interpretasi dalam memberi gambaran tentang hubungan variabel yang diteliti, sehingga akhirnya didapatkan gambaran yang jelas tentang pokok permasalahan.

Variabel terikat (Y) dalam penelitian ini adalah aspek kecukupan modal yang diukur dengan Capital Adequacy Ratio (CAR). Variabel independen (X) dalam penelitian ini adalah aspek likuiditas yang diukur dengan Financing to Deposit Ratio (FDR), dan aspek rentabilitas yang diukur dengan Return On Asset (ROA).

Definisi operasional variabel dalam penelitian ini meliputi:

Financing to Deposit Ratio (FDR)

Sebagai variabel bebas (dependen), Financing to Deposit Ratio (FDR) atau yang dalam bank konvensional disebut Loan to Deposit Ratio (LDR) ini menyatakan kemampuan bank dalam membayar kembali penarikan dana yang dilakukan deposan dengan mengendalikan kredit yang diberikan sebagai sumber likuiditasnya, atau dengan kata lain, seberapa jauh pemberian kredit kepada 
nasabah dapat mengimbangi kewajiban bank untuk segera memenuhi permintaan deposan yang hendak menarik kembali dananya yang telah disalurkan oleh bank berupa kredit.

Rumus yang digunakan untuk menghitung FDR yaitu:

$$
\text { FDR }=\frac{\text { Total Pembiayaan yang Diberikan }}{\text { Total Dana Pihak Ketiga dan Ekuitas }} \times 100 \%
$$

Return On Asset (ROA)

Sebagai variabel bebas (independen), Return On Asset (ROA) merupakan rasio yang digunakan untuk mengukur kemampuan manajemen bank dalam memperoleh laba secara keseluruhan .

Return On Asset (ROA) dipilih sebagai indikator pengukur kinerja keuntungan perbankan, karena Return On Asset (ROA) digunakan untuk mengukur efektivitas perusahaan di dalam menghasilkan keuntungan dengan memanfaatkan aktiva yang dimilikinya. Semakin besar ROA, menunjukkan kinerja keuangan yang semakin baik, karena tingkat pengembalian (return) semakin besar.

Rumus yang digunakan untuk menghitung ROA yaitu:

$$
\text { ROA }=\frac{\text { Laba Sebelum Pajak }}{\text { Total Aktiva }} \times 100 \%
$$

Capital Adequacy Ratio (CAR)

Sebagai variabel dependen (terikat), CAR adalah rasio yang memperlihatkan seberapa jauh seluruh aktiva bank yang mengandung risiko (pembiayaan, penyertaan, surat berharga, tagihan pada bank lain) ikut dibiayai dari dana modal bank, di samping memperoleh dana-dana dari sumber-sumber di luar bank seperti dana masyarakat, pinjaman (utang), dan lain-lain. Dengan kata lain, CAR adalah rasio kinerja bank untuk menunjang aktiva yang mengandung risiko, misalnya pembiayaan yang diberikan.

Rumus yang digunakan untuk menghitung CAR yaitu:

$$
\mathrm{CAR}=\frac{\text { Modal Bank }}{\text { Aktiva Tertimbang Menurut Risiko (AMTR) }} \times 100 \%
$$

Populasi dan Sampel

Populasi adalah keseluruhan subjek penelitian. Populasi adalah wilayah generalisasi yang terdiri atas objek atau subjek yang mempunyai kualitas dan karakteristik tertentu yang diterapkan oleh peneliti untuk dipelajari dan kemudian ditarik kesimpulannya. Populasi dari penelitian ini adalah laporan keuangan Bank Panin Syariah Tbk. selama 5 periode (periode tahun 2011 - 2015) yang disusun dalam periode triwulan. Dengan demikian, total populasi dalam penelitian ini sebanyak 20 bulan / peristiwa.

Sampel adalah sebagian atau wakil populasi yang akan diteliti. Sampel adalah bagian dari jumlah dan karakteristik yang dimiliki oleh populasi tersebut. Pengambilan sampel dalam penelitian ini menggunakan teknik Nonprobability, yaitu sampel jenuh atau sering disebut total sampling. Sampel jenuh yaitu teknik penentuan sampel dengan cara mengambil seluruh anggota populasi sebagai 
responden atau sampel. Sehingga jumlah sampel dalam penelitian ini sama dengan jumlah populasi, yakni sebanyak 20 (dua puluh).

Data yang digunakan adalah data sekunder berupa laporan keuangan triwulan dari Bank Panin Syariah Tbk. periode tahun 2011 sampai dengan tahun 2015. Untuk memperoleh data sekunder dalam penelitian ini, maka metode pengumpulan data yang digunakan adalah metode pengumpulan data dari basis data (Jogiyanto, 2004).

Metode ini dilakukan melalui pengumpulan dan pencatatan data laporan keuangan bank untuk mengetahui rasio-rasio keuangannya selama periode tahun 2011 2015. Data dalam penelitian ini diperoleh dari media internet dengan cara mengunduh melalui situs bank tersebut.

Guna melengkapi kajian pustaka yang relevan, maka dalam penelitian ini juga dikumpulkan bahan dari berbagai sumber seperti buku, jurnal, literatur, skripsi, dan tesis.

Data dianalisis dengan uji asumsi klasik yang meliputi uji normalitas, uji multikolinearitas, uji heteroskedastisitas, uji autokorelasi. Guna mengetahui ada atau tidaknya pengaruh antara likuiditas (FDR), rentabilitas (ROA) terhadap kecukupan modal (CAR), maka data yang telah diperoleh kemudian dianalisis dengan menggunakan metode, yakni metode analisis statistik dan analisis deskriptif komparatif yang membandingkan perubahan nilai variabel FDR, ROA, dan CAR di periode tertentu.

Metode analisis statistik dalam penelitian ini, menggunakan model analisis regresi linear berganda karena variabel independennya (FDR dan ROA) memiliki hubungan kausalitas (sebab-akibat) terhadap variabel dependennya (CAR). Rumus regresi berganda dicari dengan persamaan:

$$
\mathrm{Y}=\mathrm{a}+\mathrm{b} \_1 \mathrm{X} \_1+\mathrm{b} \_2 \mathrm{X} \_2+\mathrm{e}
$$

Keterangan:

Y : variabel dependen atau variabel terikat (CAR)

a : konstanta persamaan regresi

b1, b2 : koefisien regresi

$\mathrm{X} 1 \quad$ : variabel independen atau variabel bebas (FDR)

$\mathrm{X} 2$ : variabel independen atau variabel bebas (ROA)

e : error terms atau faktor pengganggu

Uji hipotesis dilakukan dengan uji parsial, uji simultan dan koefisien determinasi.

\section{TEMUAN}

PT. Bank Panin Dubai Syariah Tbk. ("Panin Dubai Syariah Bank"), berkedudukan di Jakarta dan berkantor pusat di Gedung Panin Life Center, Jl. Letjend S. Parman, Kav. 91, Jakarta Barat.

Sesuai dengan pasal 3 Anggaran Dasar Panin Dubai Syariah Bank, ruang lingkup kegiatan Panin Dubai Syariah Bank adalah menjalankan kegiatan usaha di bidang perbankan dengan prinsip bagi hasil berdasarkan syariat Islam. Panin Dubai 
Syariah Bank mendapat izin usaha dari Bank Indonesia berdasarkan Surat Keputusan Gubernur Bank Indonesia No. 11/52/KEP.BI/DpG/2009 tanggal 6 Oktober 2009 sebagai bank umum berdasarkan prinsip syariah dan mulai beroperasi sebagai Bank Umum Syariah pada tanggal 2 Desember 2009.

\section{Tabel 4.1}

FDR, ROA, dan CAR PT. Bank Panin Syariah Tbk. periode 2011-2015

\begin{tabular}{|c|l|c|c|c|}
\hline Tahun & \multicolumn{1}{|c|}{ Bulan } & FDR & ROA & CAR \\
\hline \multirow{4}{*}{2011} & Maret & 78.64 & -1.55 & 44.66 \\
\cline { 2 - 5 } & Juni & 97.85 & -0.79 & 100.63 \\
\cline { 2 - 5 } & September & 205.31 & 0.70 & 81.98 \\
\cline { 2 - 5 } & Desember & 162.97 & 1.75 & 61.98 \\
\hline \multirow{4}{*}{2012} & Maret & 140.35 & 2.35 & 59.72 \\
\cline { 2 - 5 } & Juni & 127.88 & 3.03 & 45.65 \\
\cline { 2 - 5 } & September & 149.82 & 2.90 & 34.48 \\
\cline { 2 - 5 } & Desember & 123.88 & 3.29 & 32.20 \\
\hline \multirow{3}{*}{2013} & Maret & 120.91 & 2.72 & 27.09 \\
\cline { 2 - 5 } & Juni & 123.60 & 2.34 & 23.11 \\
\cline { 2 - 5 } & September & 112.46 & 2.18 & 19.75 \\
\cline { 2 - 5 } & Desember & 90.40 & 1.03 & 20.83 \\
\hline & Maret & 112.84 & 1.45 & 31.15 \\
\cline { 2 - 5 } & Juni & 140.48 & 1.64 & 25.52 \\
\cline { 2 - 5 } & September & 111.79 & 1.82 & 26.16 \\
\cline { 2 - 5 } & Desember & 94.04 & 1.99 & 25.69 \\
\hline \multirow{3}{*}{2015} & Maret & 93.27 & 1.56 & 24.71 \\
\cline { 2 - 5 } & Juni & 97.58 & 1.22 & 21.17 \\
\cline { 2 - 5 } & September & 96.10 & 1.13 & 21.44 \\
\cline { 2 - 5 } & Desember & 96.43 & 1.14 & 20.30 \\
\hline
\end{tabular}

Kemudian, berikut ini disajikan fluktuasi masing-masing rasio FDR, ROA, dan CAR pada PT. Bank Panin Syariah Tbk. dalam bentuk diagram garis (line chart) beserta linear trendline guna mengetahui kecenderungan masing-masing variabel apakah meningkat atau menurun selama periode pengamatan (2011-2015).

\section{Gambar 4.2}

Fluktuasi FDR PT. Bank Panin Syariah Tbk. periode 2011-2015

Dari gambar 4.2 terlihat bahwa fluktuasi rasio FDR pada PT. Bank Panin Syariah Tbk. periode 2011-2015 adalah cenderung menurun, karena linear trendline rasio FDR bergerak turun dari sisi kanan atas ke arah sisi kiri bawah. Hal ini menggambarkan bahwa bank belum cukup stabil dalam memelihara likuiditasnya. Dari total sampel yang diteliti, sekitar $60 \%$ berada di angka lebih dari $110 \%$ dan melampaui batas maksimum yang telah ditetapkan Bank Indonesia. Titik tertinggi berada di angka $205.31 \%$ pada September 2011.

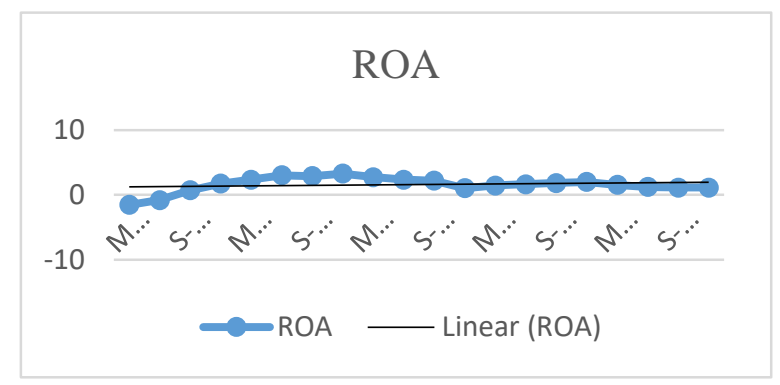

Gambar 4.3

Fluktuasi ROA PT. Bank Panin Syariah Tbk. periode 2011-2015 
Dari gambar 4.3 terlihat bahwa fluktuasi rasio ROA pada PT. Bank Panin Syariah Tbk. periode 2011-2015 adalah cenderung meningkat, karena linear trendline rasio ROA bergerak naik dari sisi kiri bawah ke arah sisi kanan atas. Hal ini menggambarkan bahwa bank cukup profitabel dalam mengelola aset untuk mendapatkan keuntungan. Dari total sampel, hampir seluruhnya berada pada kategori cukup sehat, yakni berkisar antara 0.99 hingga 1.22. Titik tertinggi berada pada di angka 3.29 pada Desember 2012.

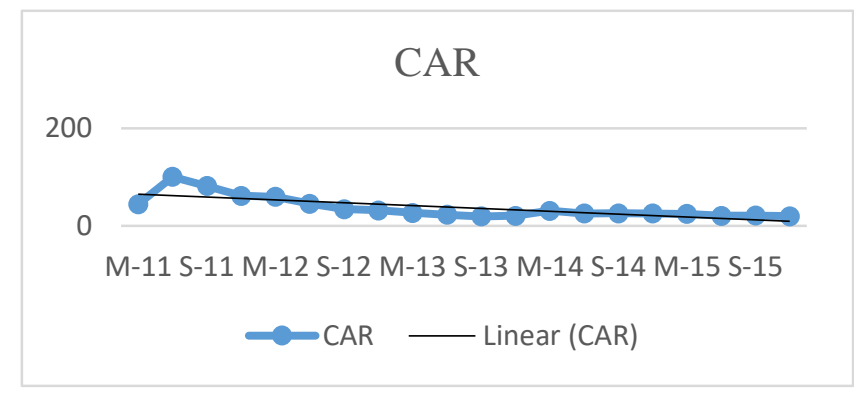

Gambar 4.4

Fluktuasi CAR PT. Bank Panin Syariah Tbk. periode 2011-2015

Dari gambar 4.4 terlihat bahwa fluktuasi rasio CAR pada PT. Bank Panin Syariah Tbk. periode 2011-2015 adalah cenderung menurun, karena linear trendline rasio FDR bergerak turun dari sisi kanan atas ke arah sisi kiri bawah. Hal ini menggambarkan bahwa bank cukup baik dalam memelihara kecukupan modalnya. Dari total sampel yang diteliti, seluruhnya berada di angka lebih dari $8 \%$ dan tidak melampaui batas minimal yang telah ditetapkan Bank Indonesia. Titik terendah berada di angka 19.75\% pada September 2013.

\section{Analisis Statistik}

\section{A. Hasil Uji Asumsi Klasik}

1. Uji Normalitas

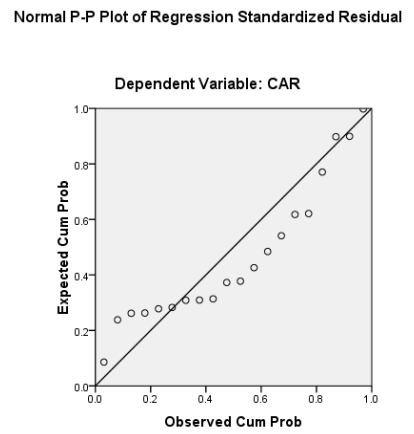

\section{Gambar 4.5}

Hasil Uji Normalitas P-Plot

Sumber: Output SPSS 16.0, Data Diolah

Berdasarkan gambar 4.5 terlihat bahwa data tersebar mendekati garis dan mengikuti arah garis diagonal yang membentuk sudut $45^{\circ}$, maka dapat disimpulkan bahwa fungsi regresi tersebut telah memenuhi asumsi normalitas 
Tabel 4.2

Hasil Uji Normalitas Kolmogorov-Smirnov

One-Sample Kolmogorov-Smirnov Test

\begin{tabular}{|c|c|c|}
\hline & & Unstandardized Residual \\
\hline $\mathrm{N}$ & & 20 \\
\hline Normal Parameters ${ }^{a}$ & Mean & .0000000 \\
\hline & $\begin{array}{l}\text { Std. } \\
\text { Deviation }\end{array}$ & 15.18900978 \\
\hline Most Extreme Differences & Absolute & .179 \\
\hline & Positive & .179 \\
\hline & Negative & -.176 \\
\hline Kolmogorov-Smirnov Z & & .802 \\
\hline Asymp. Sig. (2-tailed) & & .541 \\
\hline a. Test distribution is Norm & & \\
\hline
\end{tabular}

Sumber: Output SPSS 16.0, Data Diolah

Selain menggunakan pendekatan P-Plot, uji normalitas data juga dapat dilakukan dengan menggunakan pendekatan Kolmogorov-Smirnov. Berdasarkan tabel 4.2 di atas, diketahui nilai signifikansi adalah sebesar 0.541 (>0.05), sehingga dapat disimpulkan bahwa data berdistribusi dengan normal.

2. Uji Multikolineritas

Tabel 4.3

Hasil Uji Multikolineritas

\begin{tabular}{|c|c|c|c|c|c|c|}
\hline \multirow{2}{*}{\multicolumn{2}{|c|}{ Model }} & \multicolumn{2}{|c|}{ Unstandardized Coefficients } & \multirow{2}{*}{$\begin{array}{c}\begin{array}{c}\text { Standardized } \\
\text { Coefficients }\end{array} \\
\text { Beta }\end{array}$} & \multicolumn{2}{|c|}{ Collinearity Statistics } \\
\hline & & B & Std. Error & & Tolerance & VIF \\
\hline \multirow[t]{3}{*}{1} & (Constant) & -2.179 & 14.995 & & & \\
\hline & FDR & .488 & .130 & .655 & .893 & 1.120 \\
\hline & ROA & -11.549 & 3.277 & -.613 & .893 & 1.120 \\
\hline
\end{tabular}

a. Dependent Variable: CAR

Sumber: Output SPSS 16.0, Data Diolah

Berdasarkan tabel 4.3 menunjukan nilai VIF masing-masing variabel (FDR dan ROA) sebesar 1.120. Dari tabel di atas, terlihat bahwa semua angka VIF dari kedua variabel di bawah 10 (VIF < 10). Kemudian untuk angka tolerance, menunjukan masing-masing variabel (FDR dan ROA) memiliki angka tolerance sebesar 0.893. Terlihat bahwa semua angka tolerance dari kedua variabel di atas 0.01 (Tolerance > 0.01). Berdasarkan hal tersebut, dapat ditarik kesimpulan bahwa fungsi regresi terbebas dari masalah multikolineritas.

3. Uji Heteroskedasitas

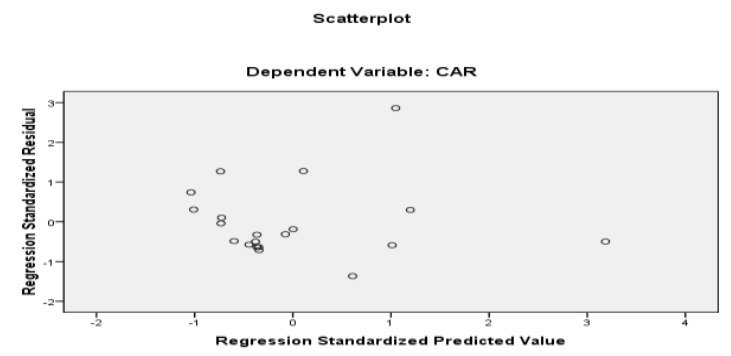




\section{Gambar 4.6 \\ Hasil Uji Heteroskedasitas}

Sumber: Output SPSS 16.0, Data Diolah

Berdasarkan gambar 4.6 terlihat bahwa plotnya menyebar secara acak, baik di atas maupun di bawah angka 0 pada sumbu $\mathrm{Y}$ dan tidak membentuk pola tertentu, maka dapat diambil kesimpulan bahwa pada fungsi regresi tersebut terbebas dari masalah heteroskedasitas.

4. Uji Autokorelasi

Tabel 4.4

Hasil Uji Autokorelasi

\begin{tabular}{l|r|r|r|r|r|}
\hline Model & R & R Square & $\begin{array}{c}\text { Adjusted R } \\
\text { Square }\end{array}$ & $\begin{array}{c}\text { Std. Error of } \\
\text { the Estimate }\end{array}$ & Durbin-Watson \\
\hline 1 & $.736^{\mathrm{a}}$ & .541 & .487 & 16.05764 & 1.862 \\
\hline
\end{tabular}
a. Predictors: (Constant), ROA, FDR
b. Dependent Variable: CAR

Sumber: Output SPSS 16.0, Data Diolah

Berdasarkan tabel 4.4 terlihat bahwa nilai Durbin-Watson sebesar 1.862 (nilai DW di antara -2 sampai +2 ), maka dapat ditarik kesimpulan bahwa fungsi regresi tersebut terbebas dari masalah autokorelasi.

\section{B. Hasil Analisis Regresi Berganda}

Tabel 4.5

Fungsi Regresi Berganda

\begin{tabular}{|c|c|c|c|c|}
\hline \multirow{2}{*}{\multicolumn{2}{|c|}{ Model }} & \multicolumn{2}{|c|}{ Unstandardized Coefficients } & \multirow{2}{*}{$\begin{array}{c}\text { Standardized } \\
\text { Coefficients } \\
\text { Beta }\end{array}$} \\
\hline & & $B$ & Std. Error & \\
\hline \multirow[t]{3}{*}{1} & (Constant) & -2.179 & 14.995 & \\
\hline & FDR & .488 & .130 & .655 \\
\hline & ROA & -11.549 & 3.277 & -.613 \\
\hline
\end{tabular}

Sumber: Output SPSS 16.0, Data Diolah

Berdasarkan tabel $4.5 \mathrm{di}$ atas, fungsi regresi yang terbentuk adalah:

$\mathbf{Y}$

$=\quad-2.170+0.488 X_{1}-11.549 X_{2}$ 
atau

CAR $=\quad-2.170+0.488$ FDR $-11.549 \mathrm{ROA}$

Dari fungsi regresi di atas, maka dapat diinterpretasikan sebagai berikut:

1. Dari persamaan di atas, diketahui nilai konstanta sebesar -2.170. Hal ini menggambarkan jika nilai kedua variabel, yaitu FDR dan ROA bernilai 0, maka nilai CAR adalah -2.170 .

2. Variabel FDR memiliki nilai koefisien regresi sebesar 0.488. Hal ini menggambarkan bahwa jika terjadi kenaikan nilai FDR sebesar 1\%, maka menyebabkan nilai CAR mengalami peningkatan sebesar $0.488 \%$, dengan asumsi variabel independen yang lain (ROA) dianggap konstan.

3. Variabel ROA memiliki nilai koefisien regresi sebesar -11.549. Hal ini menggambarkan bahwa jika terjadi kenaikan nilai ROA sebesar $1 \%$, maka menyebabkan nilai CAR mengalami penurunan sebesar $11.549 \%$, dengan asumsi variabel independen yang lain (FDR) dianggap konstan.

\section{Hasil Uji t, Uji F, dan Koefisien Determinasi}

1. Hasil Uji t

Tabel 4.6

Hasil Uji t

\begin{tabular}{|c|c|c|c|c|c|c|}
\hline \multirow{2}{*}{\multicolumn{2}{|c|}{ Model }} & \multicolumn{2}{|c|}{ Unstandardized Coefficients } & \multirow{2}{*}{$\begin{array}{c}\begin{array}{c}\text { Standardized } \\
\text { Coefficients }\end{array} \\
\text { Beta }\end{array}$} & \multirow[b]{2}{*}{$\mathrm{t}$} & \multirow[b]{2}{*}{ Sig. } \\
\hline & & B & Std. Error & & & \\
\hline \multirow[t]{3}{*}{1} & (Constant) & -2.179 & 14.995 & & -.145 & .886 \\
\hline & FDR & .488 & .130 & .655 & 3.766 & .002 \\
\hline & ROA & -11.549 & 3.277 & -.613 & -3.524 & .003 \\
\hline
\end{tabular}

a. Dependent Variable: CAR

Sumber: Output SPSS 16.0, Data Diolah

Berdasarkan tabel 4.6 di atas, hasil output dapat dijelaskan sebagai berikut:

a. Ha.1 : Likuiditas berpengaruh signifikan positif terhadap kecukupan modal Berdasarkan output di atas, diketahui nilai signifikansi adalah sebesar 0.002. Nilai signifikansi $<0.05$, sehingga dapat disimpulkan bahwa secara parsial likuiditas berpengaruh signifikan terhadap kecukupan modal. Nilai koefisien yang dimiliki sebesar 0.488, menunjukan likuiditas berhubungan positif dengan kecukupan modal. Dengan demikian, secara statistika dapat disimpulkan bahwa Ha.1 yang menyatakan likuiditas berpengaruh signifikan positif terhadap kecukupan modal yang diajukan diterima.

b. Ha.2 : Rentabilitas berpengaruh signifikan positif terhadap kecukupan modal Berdasarkan output di atas, diketahui nilai signifikansi adalah sebesar 0.003. Nilai signifikansi < 0.05 , sehingga dapat disimpulkan bahwa secara parsial rentabilitas berpengaruh signifikan terhadap kecukupan modal. Nilai koefisien yang dimiliki sebesar -11.549, menunjukan rentabilitas berhubungan negatif dengan kecukupan modal. Dengan demikian, secara statistika dapat disimpulkan bahwa Ha.2 yang 
menyatakan rentabilitas berpengaruh signifikan positif terhadap kecukupan modal yang diajukan ditolak.

2. Hasil Uji F

Tabel 4.7

Hasil Uji F

ANOVA $^{\mathrm{b}}$

\begin{tabular}{|l|r|r|r|r|r|}
\hline \multicolumn{1}{|c|}{ Model } & Sum of Squares & df & Mean Square & F & \multicolumn{1}{c|}{ Sig. } \\
\hline $1 \quad$ Regression & 5172.515 & 2 & 2586.257 & 10.030 & $.001 \mathrm{a}$ \\
Residual & 4383.414 & 17 & 257.848 & & \\
Total & 9555.929 & 19 & & & \\
\hline
\end{tabular}

a. Predictors: (Constant), ROA, FDR

b. Dependent Variable: CAR

Sumber: Output SPSS 16.0, Data Diolah

Berdasarkan tabel 4.7 di atas, diketahui bahwa nilai signifikansi sebesar 0.001 . Nilai signifikansi $0.001<0.05$, sehingga dapat disimpulkan secara simultan terdapat pengaruh likuiditas dan rentabilitas terhadap kecukupan modal. Hal ini juga menggambarkan Ha.3 yang menyatakan bahwa likuiditas dan rentabilitas berpengaruh positif secara simultan terhadap kecukupan modal yang diajukan diterima.

3. Hasil Koefisien Determinasi $\left(\mathrm{R}^{2}\right)$

Tabel 4.8

Hasil Koefisien Determinasi

\begin{tabular}{|l|r|r|r|r|}
\hline & & & & \\
Model & $\mathrm{R}$ & $\mathrm{R}$ Square & Adjusted R Square & $\begin{array}{c}\text { Std. Error of the } \\
\text { Estimate }\end{array}$ \\
\hline 1 & $.736 \mathrm{a}$ & .541 & .487 & 16.05764 \\
\hline
\end{tabular}

a. Predictors: (Constant), ROA, FDR

b. Dependent Variable: CAR

Sumber: Output SPSS 16.0, Data Diolah

Berdasarkan tabel 4.8 di atas, diketahui bahwa nilai koefisien determinasi (R2) sebesar 0,541 (nilai 0.541 adalah hasil pengkuadratan dari koefisien korelasi atau $\mathrm{R}$, yaitu sebesar $0.736 \times 0.736=0.541$ ). Besarnya angka koefisien determinasi (R2) 0.541 sama dengan $54.1 \%$. Angka tersebut menunjukan bahwa variabel FDR dan ROA berpengaruh terhadap CAR sebesar $54.10 \%$. Sedangkan sisanya (100\% - $54.1 \%=45.9 \%$ ) dipengaruhi oleh variabel-variabel lain yang tidak dimasukkan dalam analisis penelitian ini.

\section{KESIMPULAN}


Berdasarkan hasil penelitian yang telah dilakukan, maka dapat diambil beberapa kesimpulan pada Pengaruh Tingkat Likuiditas dan Rentabilitas Terhadap Kecukupan Modal Pada Bank Syariah Yang Terdaftar Di Bursa Efek Indonesia:

1. Secara parsial, variabel X1 (likuiditas) memberikan kontribusi atau pengaruh positif dan signifikan terhadap kecukupan modal. Sedangkan, variabel X2 (rentabilitas) memberikan memberikan kontribusi atau pengaruh negatif dan signifikan terhadap kecukupan modal. Berikut adalah penjelasan dari hasil uji hipotesis secara parsial:

a. Likuiditas memiliki pengaruh positif dan signifikan terhadap kecukupan modal. Hal ini terlihat dari hasil uji hipotesis parsial, yang menunjukan nilai t hitung sebesar 3.766 dan nilai signifikansi sebesar $0.002(<0.05)$.

b. Rentabilitas memiliki pengaruh negatif dan signifikan terhadap kecukupan modal. Hal ini terlihat dari hasil uji hipotesis, yang menunjukan nilai t hitung sebesar -3.524 dan nilai signifikansi sebesar $0.003(<0.05)$.

2.Secara simultan, variabel-variabel yang diuji dalam penelitian (likuiditas dan rentabilitas) memberikan kontribusi atau pengaruh positif dan signifikan terhadap kecukupan modal pada bank syariah yang terdaftar di Bursa Efek Indonesia. Hal ini dapat dilihat dari besarnya nilai $F$ hitung yaitu sebesar 10.030 dan nilai signifikansi $0.001(<0.05)$.

Penulis menyadari keterbatasan pengetahuan dan pengalaman yang dimiliki, namun walaupun demikian akan mencoba memberikan saran yang mungkin dapat bermanfaat. Adapun saran tersebut antara lain:

1. Untuk PT. Bank Panin Syariah Tbk., dengan adanya kesimpulan dari penelitian ini, maka dalam mengambil keputusan untuk mengelola kecukupan modal sebaiknya memperhatikan dan mempertimbangkan tingkat likuiditas dan rentabilitas.

2. Untuk para akademisi, penelitian ini diharapkan dapat menjadi masukan di mana perlu dikaji kembali faktor-faktor yang mempengaruhi kecukupan modal.Sehingga, penelitian ini dapat dijadikan bahan referensi yang pasti untuk menentukan faktor-faktor yang mempengaruhi kecukupan modal.

3. Untuk para peneliti lain, mengingat keterbatasan penelitian yang dilakukan penulis pada penelitian ini, disarankan untuk memperluas sampel penelitian serta menambah atau menggunakan variabel lainnya yang belum termasuk dalam penelitian ini.

\section{REFERENSI}

Abdullah, MM., M.Pd., Prof. Dr. Thamrin, Bank dan Lembaga Keuangan, Jakarta:

Rajawali Pers, 2012.

Antonio, Muhammad Syafi'i, Bank Syariah dari Teori ke Praktik, Jakarta: Gema Insani Press, 2001.

Arikunto, Suharsimi, Prosedur Penelitian Suatu Pendekatan Praktik, Jakarta: PT. Rineka Cipta, 2006. 
Damayanti, Rizka Kyky, Sujarwo, dan Taufikul Ichsan, "Pengaruh Rentabilitas dan Likuiditas Terhadap Kecukupan Modal Pada PT. Bank Syariah Mandiri Periode 2009 - 2014", Jurnal Keuangan, 2016.

Darmawi, Herman, Manajemen Perbankan, Jakarta: PT. Bumi Aksara, 2012.

Dendawijaya, Lukman, Manajemen Perbankan, Jakarta: Ghalia Indonesia, 2009.

Djarwanto, Pokok-pokok Analisa Laporan Keuangan, Yogyakarta: BPFE, 1997.

Edginarda, Cynthia, Analisis Pengaruh Rasio Rentabilitas dan Likuiditas Terhadap Capital Adequacy Ratio Pada Bank Pemerintah di Indonesia Periode 2003 - 2010, Skripsi Sarjana Universitas Hasanuddin Makassar, Tidak Diterbitkan, 2012.

Fatimah, Siti, Pengaruh Rentabilitas, Efisiensi, dan Likuiditas Terhadap Kecukupan Modal Bank Umum Syariah (Studi Kasus PT. Bank Syariah Mandiri Tbk.), Skripsi Sarjana Universitas Islam Negeri Syarif Hidayatullah Jakarta, Tidak Diterbitkan, 2013.

Ghozali, Imam, Ekonometrika: Teori, Konsep, dan Aplikasi dengan SPSS 17, Semarang: Badan Penerbit UNDIP, 2009.

Hakim, M.Ec., H. Cecep Maskanul, Belajar Mudah Ekonomi Islam, Tangerang: Shuhuf Media Insani, 2011.

Hasan, M. Iqbal, Pokok-pokok Metodologi Penelitian dan Aplikasinya, Jakart: Ghalia Indonesia, 2002.

Hasibuan, Malayu S.P., Dasar-dasar Perbankan, Jakarta: PT. Bumi Aksara, 2006. Husein, Umar, Metode Penelitian Untuk Skripsi dan Tesis Bisnis, Jakarta: PT. RajaGrafindo Persada, 2011.

Idroes, Ferry N., Manajemen Perbankan: Pemahaman Pendekatan 3 Pilar Kesepakatan Based II Terkait Aplikasi Regulasi dan Pelaksanaannya di Indonesia, Jakarta: PT. RajaGrafindo Persada, 2008.

Jogiyanto, Metodologi Penelitian Bisnis, Yogyakarta: BPFE, 2004.

Kasmir, S.E., MM., Manajemen Perbankan, Jakarta: Rajawali Press, 2003. 2007.

Maolany, Mochamad Rizal, Helliana Nurhayati, Pengaruh Likuiditas dan Profitabilitas Terhadap Kecukupan Modal Pada PT. Bank Syariah Mandiri Periode 2008 - 2013, Jurnal Ekonomi dan Akuntansi, 2015.

Margaretha, Farah, Manajemen Keuangan Bagi Industri Jasa, Jakarta: Grasindo, 2007.

Mudjarad dan Suharjono, Manajemen Perbankan Teori dan Aplikasi, Yogyakarta: BPFE, 2002.

Muhammad, Manajemen Dana Bank Syariah, Yogyakarta: Ekonisia, 2005.

Muhammad, S., "Pengaruh Rasio Kesehatan Bank Terhadap Kinerja Keuangan Bank Umum Syariah dan Bank Konvensional di Indonesia", Jurnal Manajemen dan Keuangan, 2012.

Muljono, Teguh Pudjo, Analisa Laporan Keuangan Untuk Perbankan, Jakarta: Jambatan Anggota IKPI, 1986.

Pertiwi, Eni, Pengaruh Kecukupan Modal dan Likuiditas Terhadap Profitabilitas Bank-Bank Go Public Yang Terdaftar di Bursa Efek Indonesia Pada Tahun 2011-2013, Skripsi Sarjana Universitas Wijaya Putra Surabaya, Tidak Diterbitkan, 2015. 
Prof. Dr. Sugiyono, Metode Penelitian Kuantitatif, Kualitatif, dan $R \& D$, Bandung: Alfabeta, 2013.

Purba, Daris, Pengaruh Kecukupan Modal, Likuiditas, dan Efisiensi Operasional Terhadap Profitabilitas Pada PT. Bank Muamalat Indonesia Tbk., Skripsi Sarjana Universitas Islam Negeri Syarif Hidayatullah Jakarta, Tidak Diterbitkan, 2011.

Sudarsono, Heri, Bank dan Lembaga Keuangan Syari'ah, Yogyakarta: Ekonisia, 2004.

Rivai, M.B.A. et. al., Prof. Dr. H. Veitzhal, Bank and Financial Institution Management, Jakarta: PT. RajaGrafindo Persada, 2007.

Rochaety, Ety, et. al., Metodologi Penelitian Bisnis dengan Aplikasi SPSS, Jakarta: Mitra Wacana Media, 2007.

Santoso, Singgih, Latihan SPSS Statistik Parametrik, Jakarta: PT Alex Media Komputindo, 2000.

Sastradipoera, Komaruddin, Strategi Manajemen Bisnis Perbankan, Bandung: Kappa Sigma, 2004.

Siamat, Dahlan, Manajemen Keuangan, Jakarta: Lembaga Penerbit FE UI, 2005.

Sjadeini, Sutan Remy, Perbankan Islam dan Kedudukannya dalam Tata Hukum Perbankan Indonesia, Jakarta: PT. Pustaka Umum Grafiti, 2007.

Subagyo, Metode Penelitian dalam Teori dan Praktek, Jakarta: PT. Rineka Cipta, 2004.

Sujianto, Agus Eko, Aplikasi Statistik dengan SPSS 16.0, Jakarta: Prestasi Pustaka, 2009.

Tanzeh, Ahmad, Pengantar Metode Penelitian, Yogyakarta: Teras, 2009.

Tim Penyusun, Pedoman Penulisan Skripsi, Bekasi: Sekolah Tinggi Agama Islam (STAI) Pelita Bangsa, 2017.

https://m.tempo.co/

http://www.bi.go.id/

http://www.idx.co.id/

http://www.ojk.go.id/

http://www.paninbanksyariah.co.id/ 